\title{
A pragmatic approach to the design and calibration of a Bayesian CRM dose finding trial
}

\author{
Michael Cole ${ }^{1 *}$, Deborah Stocken ${ }^{1}$, Christina Yap ${ }^{2}$ \\ From 3rd International Clinical Trials Methodology Conference \\ Glasgow, UK. 16-17 November 2015
}

The Continual Reassessment Method (CRM) is not widely used in early phase dose finding trials partly because the logistics of development and implementation are perceived as complex and time consuming. Details are presented of the steps involved when designing such a trial using an adaptation of a Bayesian CRM calibration algorithm proposed by Cheung [1].

In addition to clinician centred parameters including target toxicity probability and number of test doses, the Bayesian CRM requires specification of the prior probability of toxicity associated with each of the test doses and the prior SD of the single model parameter. Cheung's simple pragmatic approach is used to aid selection of these parameters.

Competing designs are assessed in terms of risk-adjusted accuracy and trial specific requirements including the mean number of patients treated above the maximum tolerated dose. Performance measures are estimated by Monte Carlo simulation across a range of scenarios chosen solely upon the target toxicity level and the number of test doses.

We demonstrate that following this pragmatic approach to CRM design calibration, design of CRM trials need not be overly complex or time-consuming.

\section{Authors' details \\ ${ }^{1}$ Newcastle University, Newcastle upon Tyne, UK. ${ }^{2}$ University of Birmingham, Birmingham, UK.}

\section{Published: 16 November 2015}

\section{Reference}

1. Cheung YK: Dose Finding by the Continual Reassessment Method. New York: Chapman \& Hall/CRC Press; 2011.

${ }^{1}$ Newcastle University, Newcastle upon Tyne, UK

Full list of author information is available at the end of the article
doi:10.1186/1745-6215-16-S2-P210

Cite this article as: Cole et al: A pragmatic approach to the design and calibration of a Bayesian CRM dose finding trial. Trials 2015 16(Suppl 2): P210.
Submit your next manuscript to BioMed Central and take full advantage of:

- Convenient online submission

- Thorough peer review

- No space constraints or color figure charges

- Immediate publication on acceptance

- Inclusion in PubMed, CAS, Scopus and Google Scholar

- Research which is freely available for redistribution
C Biomed Central
C Biomed Central

(c) 2015 Cole et al. This is an Open Access article distributed under the terms of the Creative Commons Attribution License (http:// creativecommons.org/licenses/by/4.0), which permits unrestricted use, distribution, and reproduction in any medium, provided the original work is properly cited. The Creative Commons Public Domain Dedication waiver (http://creativecommons.org/publicdomain/ zero/1.0/) applies to the data made available in this article, unless otherwise stated. 